\title{
X-ray structural analysis and antitumor activity of new salicylic acid derivatives
}

\author{
Evgenija A. Djurendić • Olivera R. Klisurić • Mihály Szécsi • Marija N. Sakač • \\ Suzana S. Jovanović-Šanta • Imre Ignáth • Vesna V. Kojić • Aleksandar M. Oklješa • \\ Marina P. Savić • Katarina M. Penov-Gaši
}

Received: 31 March 2014/Accepted: 17 May 2014/Published online: 6 June 2014

(C) Springer Science+Business Media New York 2014

\begin{abstract}
Tetrakis-, tris-, bis-, and mono salicylic acid derivatives 1-4 were synthesized by reaction of methyl 2-hydroxy benzoate (methyl salicylate) with 2,2-bis (hydroxymethyl) propane-1,3-diol (pentaerythritol) in the presence of sodium. Yields of different salicyloyloxy derivatives were changed by varying the molar ratios of reactants. For compounds $\mathbf{2}$ and $\mathbf{3}, \mathrm{X}$-ray structure analysis was performed, as well as molecular energy minimization, to define their conformation in terms of their energy minima. Comparison of crystal and energy minimized structures for these two compounds ( 2 and $\mathbf{3}$ ) revealed that the intramolecular hydrogen bonds play an important role, stabilizing conformation of the most part of the molecule. The antioxidant activity and cytotoxicity of the synthesized derivatives were evaluated in a series of in vitro tests, as well as 17ß-hydroxysteroid dehydrogenase type 2 inhibition potency. Tetrakis salicyloyloxy derivative $\mathbf{1}$ expressed the highest antioxidant potency, tris salicyloyloxy derivative 2 was the best inhibitor of $17 \beta$ HSD2 enzyme, while bis
\end{abstract}

E. A. Djurendić - M. N. Sakač - S. S. Jovanović-Šanta

A. M. Oklješa - M. P. Savić - K. M. Penov-Gaši

Department of Chemistry, Biochemistry and Environmental

Protection, Faculty of Sciences, University of Novi Sad, Trg

Dositeja Obradovića 3, 21000 Novi Sad, Serbia

O. R. Klisurić ( $\square)$

Department of Physics, Faculty of Sciences, University of Novi

Sad, Trg Dositeja Obradovića 4, 21000 Novi Sad, Serbia

e-mail: olivia@uns.ac.rs

M. Szécsi · I. Ignáth

First Department of Medicine, University of Szeged, Korányi

fasor 8-10, 6720 Szeged, Hungary

V. V. Kojić

Oncology Institute of Vojvodina, Put Dr Goldmana 4,

21204 Sremska Kamenica, Serbia salicyloyloxy derivative $\mathbf{3}$ showed strong cytotoxicity against prostate and breast cancer cells with no cytotoxicity against healthy cells.

Keywords Salicylic acid derivatives - Antioxidant activity $\cdot$ Cytotoxicity $\cdot$ Antitumor activity $\cdot 17 \beta-$ hydroxysteroid dehydrogenase type 2 (17 $\beta$ HSD2) inhibitors · Energy minimization $\cdot$ X-ray structural analysis

\section{Introduction}

Attacking biomolecules and thus causing cell or tissue injury, free radicals, originating from metabolism or external sources, could be included in the development of many life-limiting chronic diseases: cancer, cardiovascular diseases, rheumatism, and others [1, 2]. Increasing of antioxidants level in the body could be an effective way to prevent or exceed oxidative stress, where compounds with antioxidant potency may play a significant role. Creation or isolation from natural sources of new molecules with antioxidant properties is a very actual research area, since many naturally occurring or synthetic phenol substances proved to be strong antioxidants. Many phenol substances expressed anticancer activity against various types of carcinomas [3-8].

Salicylic acid derivatives, being phenol substances, are biologically very potent: some of them exhibited cytotoxicity against tumor cell lines, some showed antioxidant properties. In many cases, these two activities are connected [9-16].

In addition, some phenol substances could influence on the level of circulating steroids by affecting the steroidogenic enzymes, which is of high significance for the treatment of different endocrine disorders [17, 18]. For 
example, some phenol substances expressed themselves as good inhibitors of $17 \beta$-hydroxysteroid dehydrogenase type 2 (17ßHSD2), so they are used for the treatment of osteoporosis [19].

Having in mind all of these facts, in the present study, we continue our investigation of the synthesis of salicylic acid derivatives, which was described in previous papers $[14,15,20,21]$. We report a simple synthetic route for the preparation of mono-, bis-, tris-, and tetrakis salicyloyl derivatives of 2,2-bis(hydroxymethyl)-propane-1,3-diol (pentaerythritol). Two new compounds were obtained as monocrystals, which allowed their structural analysis. Biochemical studies included testing of antioxidant activity, cytotoxicity, and 17ßHSD2 inhibition potency.

\section{Experimental}

Chemical synthesis

\section{General}

IR spectra were recorded on a NEXUS 670 SP-IR spectrometer (wave numbers in $\mathrm{cm}^{-1}$ ). NMR spectra were taken on a Bruker AC $250 \mathrm{E}$ spectrometer operating at $250 \mathrm{MHz}\left({ }^{1} \mathrm{H}\right)$ and $62.5 \mathrm{MHz}\left({ }^{13} \mathrm{C}\right)$ and are reported in ppm $(\delta$-scale) downfield from the tetramethylsilane internal standard; coupling constants $(J)$ are given in Hz. Mass spectra were recorded on a Finnigan MAT 8230 instrument, using chemical ionization (isobutane) technique. All the reagents used were of analytical grade. All solutions were dried over anhydrous $\mathrm{Na}_{2} \mathrm{SO}_{4}$.

General procedure for the synthesis of propane-1,3-diyl 2,2-bis(2-hydroxybenzoyloxy)methyl bis(2-hydroxybenzoate) (1), propane-1,3-diyl 2-((2-hydroxybenzoyloxy)methyl)2-(hydroxymethyl) bis(2-hydroxybenzoate) (2), propane-1,3diyl 2,2-bis(hydroxymethyl) bis(2-hydroxybenzoate) (3) and 3-hydroxy-2,2-bis(hydroxymethyl)propyl 2-hydroxybenzoate (4).

A mixture consisting of methyl 2-hydroxybenzoate (methyl salicylate; $148 \mathrm{mmol}$ or $23 \mathrm{mmol}$ ), 2,2-bis (hydroxymethyl)propane-1,3-diol (pentaerythritol, 37 or $92 \mathrm{mmol}$ ), and sodium ( 3.7 or $7 \mathrm{mmol}$ ) was heated on an oil bath at $150{ }^{\circ} \mathrm{C}$ under atmospheric pressure with the continuos removal of methanol for $2 \mathrm{~h}$. Afterward, distilled water $(50 \mathrm{~mL})$ and hydrochloric acid $(1: 1$, to $\mathrm{pH} 6-7)$ were added to the residue. The crude product was extracted with ethyl acetate or dichloromethane $(5 \times 50 \mathrm{~mL})$, dried (anh. $\mathrm{Na}_{2} \mathrm{SO}_{4}$ ), and evaporated. Pure compounds were obtained after chromatography of crude product on silica gel column $(25 \mathrm{~g})$.

When molar ratio of methyl salicylate $(148 \mathrm{mmol})$ and 2,2-bis(hydroxymethyl)propane-1,3-diol $(37 \mathrm{mmol})$ was
$4: 1$, the precipitated solid of crude product, obtained after reaction completion, was chromatographed on silica gel column (benzene; benzene-ethyl acetate, 9:1) to give pure compound 1 in a yield of $1 \%(0.126 \mathrm{~g})$ after recrystallization from dichloromethane-hexane, $\mathrm{mp} 174-175^{\circ} \mathrm{C}$. Pure compound $\mathbf{2}$ was obtained in a yield of $19 \%$ $(2.141 \mathrm{~g})$ after recrystallization from ethyl acetate-hexane, mp $138-139{ }^{\circ} \mathrm{C}$. With further elution with benzene-ethyl acetate (4:1) pure compound 3 was obtained in a yield of $13 \%(2.00 \mathrm{~g})$ after recrystallization from acetone-hexane, mp 86.5-87 ${ }^{\circ} \mathrm{C}\left([21] 86.5-87^{\circ} \mathrm{C}\right)$.

According to the general procedure, when molar ratio of methyl 2-hydroxybenzoate $(23 \mathrm{mmol})$ and 2,2-bis (hydroxymethyl)propane-1,3-diol (92 mmol) was 1:4 (in the presence of sodium, $7 \mathrm{mmol}$ ), the pure compounds $\mathbf{2}-\mathbf{4}$ were obtained after column chromatography (benzene-ethyl acetate, 9:1, 2:1 and 1:3). Compound 2 was obtained in a yield of $3 \%\left(0.337 \mathrm{~g}, \mathrm{mp} 138^{\circ} \mathrm{C}\right.$ from dichloromethane-hexane), compound 3 in a yield of $18 \%\left(0.809 \mathrm{~g}, \mathrm{mp} 87{ }^{\circ} \mathrm{C}\right.$ from dichloromethane-hexane), and compound 4 in a yield of $3 \%\left(0.470 \mathrm{~g}, \mathrm{mp} 174-175{ }^{\circ} \mathrm{C}\right.$ from dichloromethanehexane [22]. In this reaction procedure, compound 1 was not isolated.

Compound 1: IR (KBr): 3214, 1681, 1614, 1583, 1298, $1247,1211,1158,1157,1090,755 .{ }^{1} \mathrm{H}$ NMR $\left(\mathrm{CDCl}_{3}\right)$ : $4.73\left(\mathrm{~s}, 8 \mathrm{H}, 4 \mathrm{CH}_{2}\right) ; 6.86(\mathrm{~m}, 4 \mathrm{H}, 4 \mathrm{H}-5$ from A,B,C,D rings); 6.98 (dd, $4 \mathrm{H}, 4 \mathrm{H}-3$ from $\mathrm{A}, \mathrm{B}, \mathrm{C}, \mathrm{D}$ rings, $\left.J_{(3,4)}=8.3 \mathrm{~Hz}, J_{(3,5)}=1.0 \mathrm{~Hz}\right) ; 7.49(\mathrm{~m}, 4 \mathrm{H}, 4 \mathrm{H}-4$ from A,B,C,D rings); 7.80 (dd, $4 \mathrm{H}, 4 \mathrm{H}-6$ from A,B,C,D rings, $\left.J_{(6,4)}=1.6 \mathrm{~Hz}, J_{(6,5)}=8.0 \mathrm{~Hz}\right) ; 10.47(\mathrm{~s}, 4 \mathrm{H}, 4 \mathrm{OH}$ from

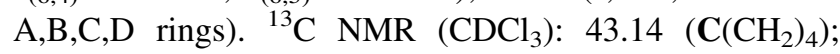
$63.31\left(4 \mathrm{CH}_{2}\right) ; 111.45$ (4C-1 from A,B,C,D rings); 117.88 (4C-3 from A,B,C,D rings); 119.44 (4C-5 from A,B,C,D rings); 129.48 (4C-6 from A,B,C,D rings); 136.39 (4C-4 from $\mathrm{A}, \mathrm{B}, \mathrm{C}, \mathrm{D}$ rings); 161.83 (4C-2 from $\mathrm{A}, \mathrm{B}, \mathrm{C}, \mathrm{D}$ rings); $169.39(4 \mathrm{C}=\mathrm{O}) . \mathrm{MS}\left(\mathrm{m} / \mathrm{z}\right.$, rel \%): $617\left(\mathrm{M}^{+}+1,100\right) ; 616$ $\left(\mathrm{M}^{+}, 7\right) ; 478$ (15). For $\mathrm{C}_{33} \mathrm{H}_{28} \mathrm{O}_{12} \times 0.3 \mathrm{C}_{6} \mathrm{H}_{6}$ (639.6) calculated: $65.31 \% \mathrm{C}, 4.66 \% \mathrm{H}$; found: $65.33 \% \mathrm{C}$, $5.01 \% \mathrm{H}$.

Compound 2: IR (KBr): 3550-3200, 2961, 1678, 1614, $1585,1485,1466,1396,1325,1299,1248,1212,1157$, 1089, 756, 699. ${ }^{1} \mathrm{H}$ NMR $\left(\mathrm{CDCl}_{3}\right): 2.54$ (bs, $\left.1 \mathrm{H}, \mathrm{CH}_{2} \mathrm{OH}\right)$; 3.85 (s, $\left.2 \mathrm{H}, \mathrm{CH}_{2} \mathrm{OH}\right) ; 4.63$ (s, $\left.6 \mathrm{H}, 3 \mathrm{CH}_{2} \mathrm{OCO}\right) ; 6.87$ (m, $3 \mathrm{H}, 3 \mathrm{H}-5$ from A,B,C rings); 6.99 (dd, $3 \mathrm{H}, 3 \mathrm{H}-3$ from A,B,C rings, $\left.J_{(3,4)}=8.2 \mathrm{~Hz}, J_{(3,5)}=1.1 \mathrm{~Hz}\right) ; 7.48(\mathrm{~m}, 3 \mathrm{H}$, 4H-4 from A,B,C rings); 7.79 (dd, 3H, 3H-6 from A,B,C rings, $\left.J_{(6,4)}=1.5 \mathrm{~Hz}, J_{(6,5)}=8.1 \mathrm{~Hz}\right) ; 10.53(\mathrm{~s}, 3 \mathrm{H}, 3 \mathrm{OH}$

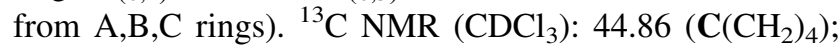
$60.79\left(\mathrm{CH}_{2} \mathrm{OH}\right) ; 63.19\left(3 \mathrm{CH}_{2} \mathrm{OCO}\right) ; 111.64$ (3C-1 from $\mathrm{A}, \mathrm{B}, \mathrm{C}$ rings); 117.84 (3C-3 from A,B,C rings); 119.40 (3C5 from $\mathrm{A}, \mathrm{B}, \mathrm{C}$ rings); 129.60 (3C-6 from $\mathrm{A}, \mathrm{B}, \mathrm{C}$ rings); 136.30 (3C-4 from A,B,C rings); 161.77 (3C-2 from A,B,C rings); $169.79(3 \mathrm{C}=\mathrm{O})$. $\mathrm{MS}\left(\mathrm{m} / \mathrm{z}\right.$, rel \%): $497\left(\mathrm{M}^{+}+1,55\right)$; 
$496\left(\mathrm{M}^{+}, 100\right) ; 376$ (12). For $\mathrm{C}_{26} \mathrm{H}_{24} \mathrm{O}_{10} \times 0.8 \mathrm{H}_{2} \mathrm{O}$ (510.8) calculated: $61.13 \% \mathrm{C}, 5.01 \% \mathrm{H}$; found: $60.94 \%$ $\mathrm{C}, 4.53 \% \mathrm{H}$.

Compound 3 was synthesized in our previous paper [21].

Compound 4: IR (KBr): $3550-3100,1680,1620,1600$, 1300, 1250, 1210, 1070, 980, 760. ${ }^{1} \mathrm{H}$ NMR $\left(\mathrm{CDCl}_{3}\right): 3.73$ $\left(\mathrm{d}, 6 \mathrm{H}, 3 \mathrm{CH}_{2} \mathrm{OH}, J=4.9 \mathrm{~Hz}\right) ; 4.08\left(\mathrm{~m}, 3 \mathrm{H}, 3 \mathrm{CH}_{2} \mathrm{OH}\right)$; 4.44 (s, $\left.2 \mathrm{H}, \mathrm{CH}_{2} \mathrm{OCO}\right) ; 6.94$ (m, 2H, H-5 and $\mathrm{H}-3$ from A ring); $7.52(\mathrm{~m}, 1 \mathrm{H}, \mathrm{H}-4$ from $\mathrm{A}$ ring); $7.89(\mathrm{dd}, 1 \mathrm{H}, \mathrm{H}-6$ from A ring $\left.J_{(6,4)}=1.8 \mathrm{~Hz}, J_{(6,5)}=8.2 \mathrm{~Hz}\right) ; 10.74(\mathrm{~s}, 1 \mathrm{H}$, $\mathrm{OH}$ from A ring). ${ }^{13} \mathrm{C}$ NMR $\left(\mathrm{CDCl}_{3}\right): 46.00\left(\left(\mathrm{CH}_{2}\right)\right.$ $\left.\mathrm{C}\left(\mathrm{CH}_{2} \mathrm{OH}\right)_{3}\right) ; 62.72\left(3 \mathrm{CH}_{2} \mathrm{OH}\right) ; 65.23\left(\mathrm{CH}_{2} \mathrm{OCO}\right) ; 113.57$ (C-1 from A ring); 118.17 (C-3 from A ring); 120.07 (C-5 from A ring); 130.86 (C-6 from A ring); 136.53 (C-4 from A ring); 162.20 (C-2 from A ring); $170.73(\mathrm{C}=\mathrm{O})$. MS $(\mathrm{m} / \mathrm{z}$, rel \%): $257\left(\mathrm{M}^{+}+1,100\right) ; 239$ (2); 161 (2); 120 (2). For $\mathrm{C}_{12} \mathrm{H}_{16} \mathrm{O}_{6}(256.2)$ calculated: $56.24 \% \mathrm{C}, 6.29 \% \mathrm{H}$; found: $56.36 \% \mathrm{C}, 6.05 \% \mathrm{H}$.

\section{Crystal structure determination}

The diffraction data for compounds $\mathbf{2}$ and $\mathbf{3}$ were collected at room temperature on an Oxford Diffraction (Agilent Technologies) Xcalibur diffractometer with graphitemonochromated MoK $\alpha$ radiation $(\lambda=0.7107 \AA)$. The data reduction was performed with program package CrysAlis RED [23]. The space group determinations were based on an analysis of the Laue class and the systematically absent reflections. The structures were solved by direct methods using SIR92 [24]. All structures were refined using fullmatrix least-squares. For all three compounds, non-hydrogen atoms were refined anisotropically, the $\mathrm{C}-\mathrm{H}$ hydrogen atoms were included on calculated positions riding on their attached atoms with fixed distances $0.97 \AA\left(\mathrm{CH}_{2}\right)$ and $0.96 \AA\left(\mathrm{CH}_{3}\right)$. At the final stage of the refinement, $\mathrm{H}$ atoms from the hydroxyl group were positioned geometrically $(\mathrm{O}-\mathrm{H}=0.82 \AA)$ and refined using a riding model with fixed isotropic displacement parameters. All calculations were performed using SHELXL97 [25], PARST [26], and PLATON [27], as implemented in the WINGX [28] system of programs. The crystal data and refinement parameters are summarized in Table 1.

\section{Biological tests}

\section{Free radical scavenging assays}

Free radical scavenging capacity (RSC) of the synthesized compounds was evaluated by measuring their ability to neutralize 2,2-diphenyl-1-picrylhydrazyl (DPPH·) and $\mathrm{HO}$. radicals. Final concentrations of the tested compounds were in the range of $0.01-8 \mathrm{mM}$.

\section{DPPH assay}

The DPPH assay was performed as described before [14]. The different aliquots $(0.10-2.00 \mathrm{~mL})$ of $0.01 \mathrm{M}$ sample solution in methanol were added to $1.00 \mathrm{~mL}$ of $90 \mu \mathrm{M}$ DPPH in methanol (Sigma; St. Louis, MO) and filled up with $95 \%(\mathrm{v} / \mathrm{v})$ methanol to a final volume of $4.00 \mathrm{~mL}$. The same reaction mixture without the tested compounds was used as the control. Absorbencies of the reaction mixtures and control were recorded at $515 \mathrm{~nm}$ (CECIL CE2021 spectrophotometer) after $1 \mathrm{~h}$. Commercial synthetic antioxidants, 3,5-di-tert-butyl-4-hydroxytoluene (BHT) (Aldrich; Taufkirchen, Germany) and 3-tert-butyl4-hydroxyanisole (BHA) (Fluka; Taufkirchen, Germany) were used as positive controls. For each sample, three replicates were recorded.

The percentage of DPPH radical scavenging capacity (DPPH RSC) was calculated using the following equation:

$\operatorname{RSC}(\%)=100 \times\left(A_{\text {control }}-A_{\text {sample }} / A_{\text {control }}\right)$.

$\mathrm{IC}_{50}$ values (the concentration of the tested compound in the reaction mixture which causes $50 \%$ of RSC) were determined by linear regression analysis from the obtained RSC values.

\section{Hydroxyl-radical scavenging assay}

Hydroxyl-radicals scavenging capacity (OH RSC) of the tested compounds was evaluated by measuring the degradation of 2-deoxy-D-ribose (Aldrich; Taufkirchen, Germany) in the reaction with $\mathrm{OH}$ radicals, generated in situ in Fenton's reaction [14]. These radicals attack 2-deoxy-Dribose and degrade it into a series of fragments, some or all of which react with 2-thiobarbituric acid (TBA) (Sigma; St. Louis, $\mathrm{MO}$ ) at low $\mathrm{pH}$ and high temperature to give a pink chromogen, which can be determined spectrophotometrically at $532 \mathrm{~nm}$. Different aliquots $(0.005-0.5 \mathrm{~mL})$ of sample solution in methanol were added to test tubes (final concentration ranged from 0.01 to $8 \mathrm{mM}$ ), each containing $0.1 \mathrm{~mL}$ of $5 \mathrm{mM} \mathrm{H}_{2} \mathrm{O}_{2}, 0.1 \mathrm{~mL}$ of $10 \mathrm{mM} \mathrm{FeSO}_{4}$, and $0.1 \mathrm{~mL}$ of $0.05 \mathrm{M}$ 2-deoxy-D-ribose and $0.067 \mathrm{M} \mathrm{KH}_{2}$ $\mathrm{PO}_{4}-\mathrm{K}_{2} \mathrm{HPO}_{4}$ buffer $\mathrm{pH} 7.4$ to a final volume of $3.00 \mathrm{~mL}$. The same reaction mixture without sample was used as the control. After an incubation period of $1 \mathrm{~h}$ at $37^{\circ} \mathrm{C}, 2 \mathrm{~mL}$ of TBA reagent $\left(10.4 \mathrm{~mL}\right.$ of $60 \%(\mathrm{v} / \mathrm{v}) \mathrm{HClO}_{4}, 3 \mathrm{~g}$ TBA and $120 \mathrm{~g}$ of trichloroacetic acid (Sigma; St. Louis, MO), and $0.2 \mathrm{~mL}$ of $0.1 \mathrm{M}$ EDTA (Sigma; St. Louis, MO) were added to the reaction mixture, and the tubes were heated at $100{ }^{\circ} \mathrm{C}$ for $20 \mathrm{~min}$. After cooling, absorbencies of the reaction mixtures and of the control were recorded at 
Table 1 Experimental details: crystallographic data and refinement parameters

\begin{tabular}{|c|c|c|}
\hline & 2 & 3 \\
\hline Chemical formula & $\mathrm{C}_{26} \mathrm{H}_{24} \mathrm{O}_{10}$ & $\mathrm{C}_{38} \mathrm{H}_{40} \mathrm{O}_{16}$ \\
\hline$M_{r}$ & 496.45 & 752.70 \\
\hline Cell setting, space group & Hexagonal, $\bar{R} 3$ & Monoclinic, $P 2{ }_{1} / c$ \\
\hline Temperature (K) & 293 & 293 \\
\hline$a(\AA), b(\AA), c(\AA)$ & & $\begin{array}{l}8.5196(3), 15.2951(5) \\
28.0026(9)\end{array}$ \\
\hline$a(\AA), c(\AA)$ & $13.3220(7), 22.1447$ (14) & \\
\hline$\beta\left(^{\circ}\right)$ & & $97.082(3)$ \\
\hline$V\left(\AA^{3}\right)$ & $3,403.6(3)$ & $3,621.1(2)$ \\
\hline$Z$ & 6 & 4 \\
\hline$D_{x}\left(\mathrm{mg} \mathrm{m}^{-3}\right)$ & 1.447 & 1.381 \\
\hline Radiation type & Mo $K \alpha$ & Mo $K \alpha$ \\
\hline$\mu\left(\mathrm{mm}^{-1}\right)$ & 0.11 & 0.11 \\
\hline Crystal size (mm) & $0.54 \times 0.53 \times 0.24$ & $0.48 \times 0.27 \times 0.16$ \\
\hline Diffractometer & Goniometer Xcalibur, detector: Sapphire3 (Gemini) & \\
\hline \multirow[t]{2}{*}{ Absorption correction } & Multi-scan & \\
\hline & \multicolumn{2}{|c|}{$\begin{array}{l}\text { CrysAlis PRO, Oxford Diffraction Ltd., Version 1.171.33.66 (release 28-04-2010 } \\
\text { CrysAlis171.NET) (compiled Apr 28 2010,14:27:37) Empirical absorption correction using } \\
\text { spherical harmonics, implemented in SCALE3 ABSPACK scaling algorithm }\end{array}$} \\
\hline$T_{\min }$ & 0.993 & 0.975 \\
\hline$T_{\max }$ & 1.000 & 1.000 \\
\hline $\begin{array}{l}\text { No. of measured, independent and observed } \\
\text { reflections }\end{array}$ & $2,388,1,331,944$ & $18,533,6,357,3,585$ \\
\hline$R_{\text {int }}$ & 0.013 & 0.036 \\
\hline$(\sin \theta / \lambda)_{\max }\left(\AA^{-1}\right)$ & 0.594 & 0.595 \\
\hline$R\left[F^{2}>2 \sigma\left(F^{2}\right)\right], w R\left(F^{2}\right), S$ & $0.048,0.139,1.08$ & $0.044,0.110,0.90$ \\
\hline No. of reflections & 1,331 & 6,357 \\
\hline No. of parameters & 123 & 494 \\
\hline No. of restraints & 1 & 0 \\
\hline H-atom treatment & $\begin{array}{l}\mathrm{H} \text { atoms treated by a mixture of independent and constrained } \\
\text { refinement }\end{array}$ & $\begin{array}{l}\mathrm{H} \text {-atom parameters } \\
\text { constrained }\end{array}$ \\
\hline Weighting scheme & $\begin{array}{l}w=1 /\left[\sigma^{2}\left(F_{\mathrm{o}}^{2}\right)+(0.0753 P)^{2}+0.8349 P\right] \\
\text { where } P=\left(F_{\mathrm{o}}^{2}+2 F_{\mathrm{c}}^{2}\right) / 3\end{array}$ & $\begin{array}{l}w=1 /\left[\sigma^{2}\left(F_{\mathrm{o}}^{2}\right)+(0.0582 P)^{2}\right] \\
\text { where } P=\left(F_{\mathrm{o}}^{2}+2 F_{\mathrm{c}}^{2}\right) / 3\end{array}$ \\
\hline$\Delta \rho_{\max }, \Delta \rho_{\min }\left(\mathrm{e} \AA^{-3}\right)$ & $0.40,-0.42$ & $0.35,-0.27$ \\
\hline
\end{tabular}

$532 \mathrm{~nm}$. Percentage of HO RSC was calculated using the following equation:

$\operatorname{RSC}(\%)=100 \times\left(A_{\text {control }}-A_{\text {sample }} / A_{\text {control }}\right)$

Three replicates were recorded for each sample. BHT and BHA were used as reference compounds. $\mathrm{IC}_{50}$ values (the concentration at which $50 \%$ of $\mathrm{HO}$ is neutralized) were determined by linear regression analysis from the obtained RSC values.

\section{Cytotoxic activity}

The cytotoxicity of the synthesized compounds was evaluated using previously described method [29]. The chemotherapy drug doxorubicin (Dox), used as control, was tested under the same experimental conditions.

\section{Cell lines}

Three human tumor and one normal cell lines were used in this study: estrogen-receptor positive human breast adenocarcinoma (ER+, MCF-7), estrogen-receptor negative human breast adenocarcinoma (ER-, MDA-MB-231), human prostate cancer (PC-3), and normal fetal lung fibroblasts (MRC-5). These cells were grown in Dulbecco's modified Eagle's medium with $4.5 \%$ of glucose. Media were supplemented with $10 \%$ of fetal calf serum and antibiotics $(100 \mathrm{IU} / \mathrm{mL}$ of penicillin and $100 \mu \mathrm{g} / \mathrm{mL}$ of 


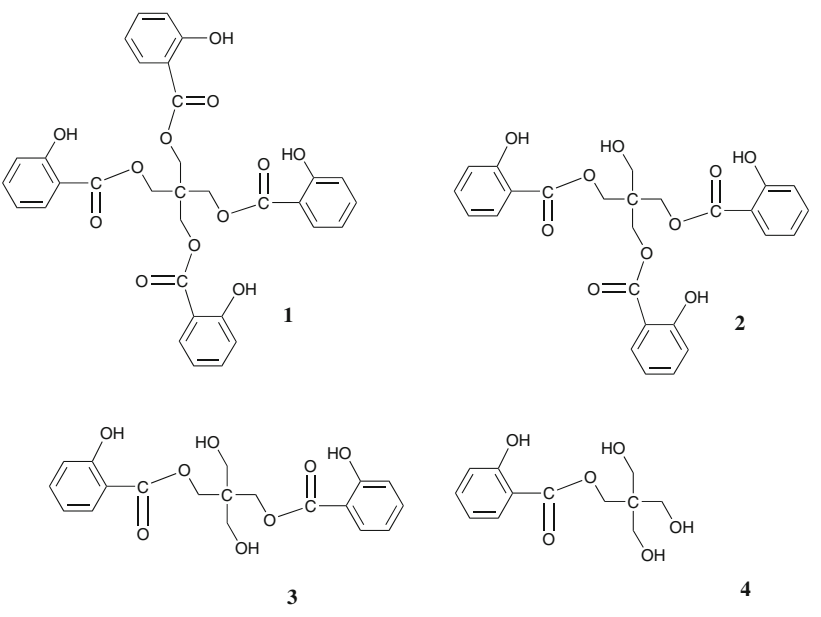

Fig. 1 The structures of compounds (1-4) obtained in the reaction of methyl salicylate with pentaerythritol

Table 2 Molar ratios of reactants and yields of compounds 1-4

Molar ratio

\begin{tabular}{lll}
\hline Compound & \multicolumn{1}{c}{ Yield $(\%)$} & $1: 4$ \\
\cline { 2 - 3 } & $4: 1$ & - \\
\hline $\mathbf{1}$ & 1 & 3 \\
$\mathbf{2}$ & 19 & 18 \\
$\mathbf{4}$ & 13 & 3 \\
\hline
\end{tabular}

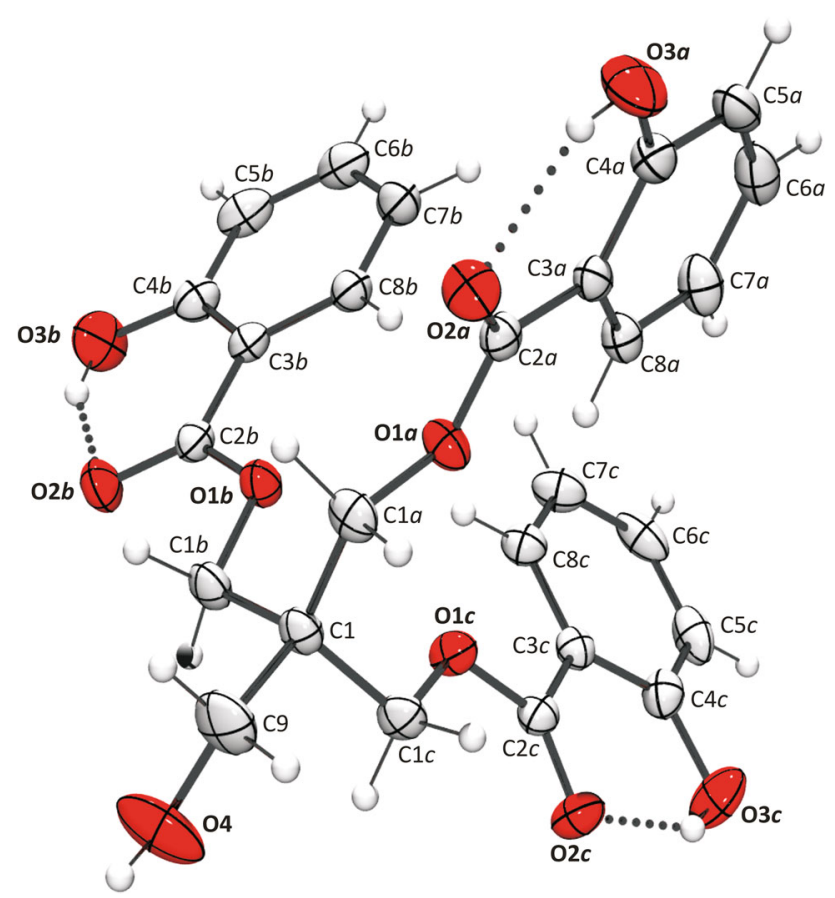

Fig. 2 ORTEP drawing of molecular structures of compound 2 with the labeling of non-H atoms. Displacement ellipsoids are shown at the $30 \%$ probability level and $\mathrm{H}$ atoms are drawn as spheres of arbitrary radii. Intramolecular hydrogen bonds are shown as dashed lines streptomycin; ICN Galenika). All cell lines were cultured in flasks (Costar, $25 \mathrm{~cm}^{2}$ ) at $37{ }^{\circ} \mathrm{C}$ in $100 \%$ humidity atmosphere and $5 \%$ of $\mathrm{CO}_{2}$ incubator. Only viable cells were used in the assay. Viability was determined by dye exclusion assay with trypan blue.

\section{Cytotoxicity assay}

Cytotoxicity was evaluated by colorimetric sulforhodamine B (SRB) assay [29]. In brief, single cell suspension $\left(5 \times 10^{3}\right.$ cells) was plated into 96 -well microtiter plates (Costar, flat bottom). Plates were pre-incubated at $37{ }^{\circ} \mathrm{C}$ in a $5 \% \mathrm{CO}_{2}$ incubator during $24 \mathrm{~h}$. Tested substances (at final concentrations ranging from $10^{-8}$ to $10^{-4} \mathrm{M}$ ) were added to all wells except the control ones. After incubation period $\left(48 \mathrm{~h} / 37{ }^{\circ} \mathrm{C} / 5 \% \mathrm{CO}_{2}\right)$, cytotoxicity assay was carried out as follows: $50 \mu \mathrm{L}$ of $80 \%$ trichloroacetic acid was added to all wells; an hour later, the plates were washed with distilled water, and $75 \mu \mathrm{L}$ of $0.4 \%$ SRB was added to all wells; 30 min later the plates were washed with citric acid $(1 \%)$ and dried at room temperature. Finally, $200 \mu \mathrm{L}$ of $10 \mathrm{mM}$ Tris $(\mathrm{pH} 10.5)$ basis was added to all wells. Absorbance was measured on the microplate reader. The wells containing complete medium only, without cells, acted as blank. Cytotoxicity was calculated according to the formula:

CI $(\%)=\left(1-A_{\text {sample }} / A_{\text {control }}\right) \times 100$.

Two independent experiments were set out in quadruplicate for each concentration of the compound. The $\mathrm{IC}_{50}$ (value that defines the dose of compound that inhibits cell growth by $50 \%$ ) of compounds was determined by Median effect analysis.

\section{Determination of $17 \beta H S D 2$ activity and its inhibition in the rat liver microsomal preparation}

Inhibitory effects exerted on the $17 \beta \mathrm{HSD} 2$ activity by the newly synthesized compounds (1-3) were investigated via conversion of testosterone to androst-4-ene-3,17-dione in vitro. Our previously published radioincubation method for $3 \beta \mathrm{HSD}[30,31]$ was modified and adapted to the $17 \beta$ HSD2 measurements. Female rat liver expresses $17 \beta$ HSD 2 constitutively [32], and served as feasible source of this isozyme. Liver tissue of adult female Wistar rats was homogenized with an Ultra-Turrax in 0.1 M HEPES buffer ( $\mathrm{pH}$ 7.3) containing $1 \mathrm{mM}$ EDTA and $1 \mathrm{mM}$ dithiothreitol and microsomes were obtained with fractionated centrifugation. Aliquots of the microsomal preparate were incubated with $1 \mu \mathrm{M}\left[{ }^{14} \mathrm{C}\right]$ testosterone in the presence of $1 \mathrm{mM}$ NAD. $\left[{ }^{14} \mathrm{C}\right]$ testosterone was added to the incubate in $10 \mu \mathrm{L}$ of a $25 \mathrm{v} / \mathrm{v} \%$ propylene glycol in HEPES buffer solution, whereas test compounds were applied in $10 \mu \mathrm{L}$ of 


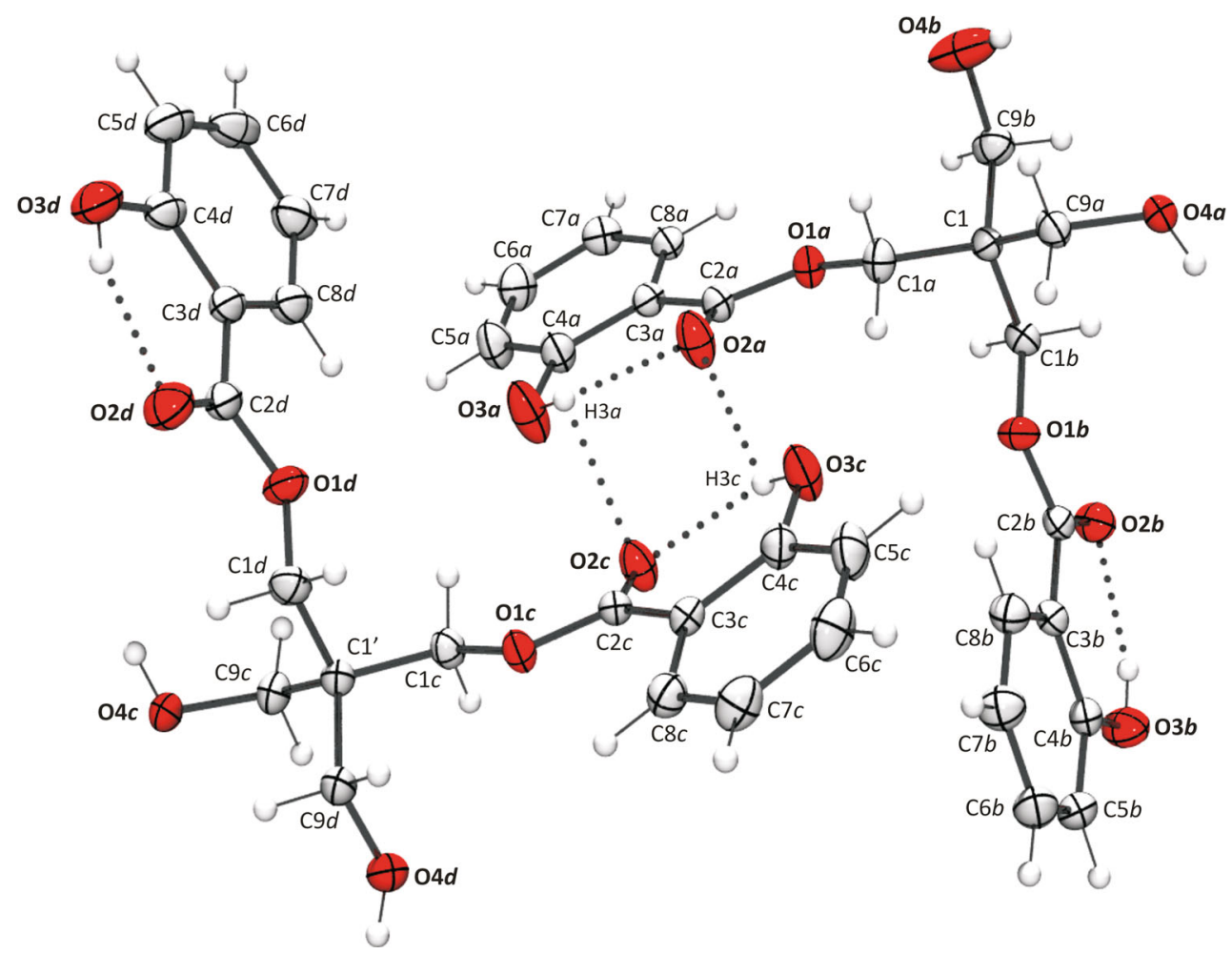

Fig. 3 ORTEP drawing of molecular structures of compound 3 with the labeling of non-H atoms. Displacement ellipsoids are shown at the $30 \%$ probability level and $\mathrm{H}$ atoms are drawn as spheres of arbitrary radii. Intramolecular hydrogen bonds are shown as dashed lines

dimethyl sulfoxide solution. These organic solvent contents of $200 \mu \mathrm{L}$ final volume of the incubation medium did not reduce the enzyme activity substantially. Incubation was carried out at $37^{\circ} \mathrm{C}$ for 20 min and the enzymatic reaction was stopped by the addition of ethyl acetate and freezing. After extraction, unlabeled carriers of testosterone and the product androst-4-ene-3,17-dione were added to the samples. The two steroids were separated by TLC on Kieselgel-G (Merck Si $254 \mathrm{~F}$ ) layers $(0.25-\mathrm{mm}$ thick) with the solvent system diisopropyl ether- $\mathrm{CH}_{2} \mathrm{Cl}_{2}(50: 50 \mathrm{v} / \mathrm{v})$ and UV spots were used to trace the separated steroids. Spots were cut out and the radioactivity of the androst-4-ene3,17-dione formed and of the testosterone remaining was measured by means of liquid scintillation counting. Test compounds were applied at $50 \mu \mathrm{M}$ concentrations and control incubates without test substances were also prepared in every series. At least two experiments were performed with each test compound and the standard deviations of the mean enzyme activity results were within $\pm 10 \%$. $\mathrm{IC}_{50}$ values were determined for more potent inhibitors. In this case, conversion was measured at five or six different concentrations of the test compound between 0.1 and $50 \mu \mathrm{M} . \mathrm{IC}_{50}$ results were calculated by linear regression analysis following a logit-log transformation of the data, and the standard deviations were determined from the fitted lines.

\section{Results and discussion}

Chemistry

Tetrakis-, tris-, bis-, and mono- salicyloyloxy derivatives 1-4 were synthesized by reaction of methyl salicylate with 2,2-bis (hydroxymethyl)propane-1,3-diol in the presence of sodium, at $150{ }^{\circ} \mathrm{C}$ for $2 \mathrm{~h}$ (Fig. 1). The molar ratios of reactants were varied in order to increase the yield of the desired products (Table 2). When molar ratio of methyl salicylate and 2,2-bis (hydroxymethyl)propane-1,3-diol was $4: 1$, tetrakis derivative 1 was obtained in only $1 \%$ yield, while it was not obtained when molar ratio of reactants was 1:4. Tris derivative $\mathbf{2}$ was formed in the yield of $19 \%$ (molar ratio $4: 1$ ), while in ratio $1: 4$ only $3 \%$ of 2 were obtained. Compound $\mathbf{3}$ was obtained in 18 and $13 \%$ yield, in molar ratios 1:4 and 4:1, respectively. Mono salicylic acid derivative 4 , however, was obtained only when molar ratio was $1: 4$, in a very low yield (3\%).

\section{Crystal structures analyses}

An ORTEP drawings of molecular structures of compound $\mathbf{2}$ and $\mathbf{3}$ are depicted in Figs. 2 and 3, respectively, while selected bond distances, bond angles, and torsion angles within these compounds are given in Table 3. 
Table 3 Selected bond lengths $(\AA)$, angles $\left(^{\circ}\right)$ and torsion angles $\left(^{\circ}\right)$

\begin{tabular}{|c|c|c|c|}
\hline \multicolumn{2}{|l|}{ Compound 2} & \multicolumn{2}{|l|}{ Compound $\mathbf{3}$} \\
\hline \multicolumn{2}{|l|}{ Bond } & \multicolumn{2}{|l|}{ Bond } \\
\hline $\mathrm{O} 1 a-\mathrm{C} 1 a$ & $1.445(3)$ & $\mathrm{O} 1 a-\mathrm{C} 1 a$ & $1.454(3)$ \\
\hline $\mathrm{O} 1 b-\mathrm{C} 1 b$ & & $\mathrm{O} 1 b-\mathrm{C} 1 b$ & $1.445(2)$ \\
\hline \multirow[t]{2}{*}{$\mathrm{O} 1 \mathrm{c}-\mathrm{C} 1 c$} & & $\mathrm{O} 1 c-\mathrm{C} 1 c$ & $1.443(3)$ \\
\hline & & $\mathrm{O} 1 d-\mathrm{C} 1 d$ & $1.442(2)$ \\
\hline $\mathrm{O} 1 a-\mathrm{C} 2 a$ & $1.340(3)$ & $\mathrm{O} 1 a-\mathrm{C} 2 a$ & $1.339(2)$ \\
\hline $\mathrm{O} 1 b-\mathrm{C} 2 b$ & & $\mathrm{O} 1 b-\mathrm{C} 2 b$ & $1.340(3)$ \\
\hline \multirow[t]{2}{*}{$\mathrm{O} 1 c-\mathrm{C} 2 \mathrm{c}$} & & $\mathrm{O} 1 c-\mathrm{C} 2 c$ & $1.330(2)$ \\
\hline & & $\mathrm{O} 1 d-\mathrm{C} 2 d$ & $1.332(3)$ \\
\hline $\mathrm{O} 2 a-\mathrm{C} 2 a$ & $1.219(2)$ & $\mathrm{O} 2 a-\mathrm{C} 2 a$ & $1.216(2)$ \\
\hline $\mathrm{O} 2 b-\mathrm{C} 2 b$ & & $\mathrm{O} 2 b-\mathrm{C} 2 b$ & $1.220(2)$ \\
\hline \multirow[t]{2}{*}{$\mathrm{O} 2 c-\mathrm{C} 2 c$} & & $\mathrm{O} 2 c-\mathrm{C} 2 c$ & $1.215(2)$ \\
\hline & & $\mathrm{O} 2 d-\mathrm{C} 2 d$ & $1.210(2)$ \\
\hline C9-O4 & $1.3960(10)$ & $\mathrm{O} 4 a-\mathrm{C} 9 a$ & $1.425(2)$ \\
\hline $\mathrm{C} 9-\mathrm{O} 4^{\prime \mathrm{i}}$ & & $\mathrm{O} 4 b-\mathrm{C} 9 b$ & $1.420(3)$ \\
\hline \multirow[t]{2}{*}{$\mathrm{C} 9-\mathrm{O} 4^{\prime \prime i i ~}$} & & $\mathrm{O} 4 c-\mathrm{C} 9 c$ & $1.425(2)$ \\
\hline & & $\mathrm{O} 4 d-\mathrm{C} 9 d$ & 1.419 (3) \\
\hline Angle & \multicolumn{3}{|c|}{ Angle } \\
\hline $\mathrm{C} 1 b^{\mathrm{i}}-\mathrm{C} 1-\mathrm{C} 1 c^{\mathrm{ii}}$ & $113.00(13)$ & $\mathrm{C} 1 a-\mathrm{C} 1-\mathrm{C} 1 b$ & $112.39(17)$ \\
\hline $\mathrm{C} 1 b^{\mathrm{i}}-\mathrm{C} 1-\mathrm{C} 1 a$ & & $\mathrm{C} 1 d-\mathrm{C}^{\prime}-\mathrm{C} 1 c$ & $111.79(18)$ \\
\hline \multicolumn{4}{|l|}{$\mathrm{C} 1 c^{\mathrm{ii}-}-\mathrm{C} 1-\mathrm{C} 1 a$} \\
\hline $\mathrm{C} 1 a-\mathrm{C} 1-\mathrm{C} 9$ & $105.66(15)$ & $\mathrm{C} 1 a-\mathrm{C} 1-\mathrm{C} 9 a$ & $104.02(15)$ \\
\hline $\mathrm{C} 1 b^{\mathrm{i}}-\mathrm{C} 1-\mathrm{C} 9$ & & $\mathrm{C} 1 b-\mathrm{C} 1-\mathrm{C} 9 b$ & $106.75(16)$ \\
\hline \multirow[t]{2}{*}{$\mathrm{C} 1 c^{\mathrm{ii}-\mathrm{C} 1-\mathrm{C} 9}$} & & $\mathrm{C} 1 c-\mathrm{Cl}^{\prime}-\mathrm{C} 9 c$ & $106.08(16)$ \\
\hline & & $\mathrm{C} 1 d-\mathrm{Cl}^{\prime}-\mathrm{C} 9 d$ & $106.09(17)$ \\
\hline $\mathrm{O} 4-\mathrm{C} 9-\mathrm{C} 1$ & $115.8(3)$ & $\mathrm{O} 4 a-\mathrm{C} 9 a-\mathrm{C} 1$ & $112.99(16)$ \\
\hline $\mathrm{O} 4^{\prime \mathrm{i}}-\mathrm{C} 9-\mathrm{C} 1$ & & $\mathrm{O} 4 b-\mathrm{C} 9 b-\mathrm{C} 1$ & $111.27(17)$ \\
\hline \multirow[t]{2}{*}{$\mathrm{O} 4{ }^{\prime \prime i i}-\mathrm{C} 9-\mathrm{C} 1$} & & $\mathrm{O} 4 c-\mathrm{C} 9 c-\mathrm{C}^{\prime}$ & $113.69(18)$ \\
\hline & & $\mathrm{O} 4 d-\mathrm{C} 9 d-\mathrm{C}^{\prime}$ & $108.97(18)$ \\
\hline Torsion angle & & Torsion angle & \\
\hline $\mathrm{C} 1 a-\mathrm{C} 1-\mathrm{C} 9-\mathrm{O} 4$ & $-65.2(4)$ & $\mathrm{C} 1 a-\mathrm{C} 1-\mathrm{C} 9 b-\mathrm{O} 4 b$ & $58.5(3)$ \\
\hline $\mathrm{C} 1 b^{\mathrm{i}}-\mathrm{C} 1-\mathrm{C} 9-\mathrm{O} 4^{\prime \mathrm{i}}$ & & $\mathrm{C} 1 b-\mathrm{C} 1-\mathrm{C} 9 a-\mathrm{O} 4 a$ & $57.5(2)$ \\
\hline \multirow[t]{2}{*}{ 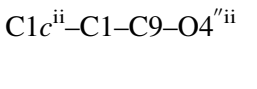 } & & $\mathrm{C} 1 c-\mathrm{C}^{\prime}-\mathrm{C} 9 d-\mathrm{O} 4 d$ & $-55.3(2)$ \\
\hline & & $\mathrm{C} 1 d-\mathrm{C} 1^{\prime}-\mathrm{C} 9 c-\mathrm{O} 4 c$ & $-53.6(2)$ \\
\hline $\mathrm{C} 1 a-\mathrm{C} 1-\mathrm{C} 9-\mathrm{O} 4^{\prime \mathrm{i}}$ & $54.8(4)$ & $\mathrm{C} 9 a-\mathrm{C} 1-\mathrm{C} 9 b-\mathrm{O} 4 b$ & $-57.2(3)$ \\
\hline $\mathrm{C} 1 b^{\mathrm{i}}-\mathrm{C} 1-\mathrm{C} 9-\mathrm{O} 4^{\prime \prime \mathrm{ii}}$ & & $\mathrm{C} 9 b-\mathrm{C} 1-\mathrm{C} 9 a-\mathrm{O} 4 \mathrm{a}$ & $-61.0(2)$ \\
\hline \multirow[t]{2}{*}{$\mathrm{C} 1 c^{\mathrm{ii}}-\mathrm{C} 1-\mathrm{C} 9-\mathrm{O} 4$} & & $\mathrm{C} 9 c-\mathrm{C} 1^{\prime}-\mathrm{C} 9 d-\mathrm{O} 4 d$ & $62.7(2)$ \\
\hline & & $\mathrm{C} 9 d-\mathrm{C} 1^{\prime}-\mathrm{C} 9 c-\mathrm{O} 4 c$ & $64.3(2)$ \\
\hline $\mathrm{C} 1 a-\mathrm{C} 1-\mathrm{C} 9-\mathrm{O} 4^{\mathrm{ii}}$ & $174.8(4)$ & $\mathrm{C} 1 a-\mathrm{C} 1-\mathrm{C} 9 a-\mathrm{O} 4 a$ & $178.52(16)$ \\
\hline 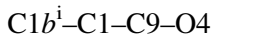 & & $\mathrm{C} 1 b-\mathrm{C} 1-\mathrm{C} 9 b-\mathrm{O} 4 b$ & $-178.1(2)$ \\
\hline \multirow[t]{2}{*}{$\mathrm{C} 1 c^{\mathrm{ii}}-\mathrm{C} 1-\mathrm{C} 9-\mathrm{O} 4^{\mathrm{i}}$} & & $\mathrm{C} 1 c-\mathrm{C}^{\prime}-\mathrm{C} 9 c-\mathrm{O} 4 c$ & $-174.97(17)$ \\
\hline & & $\mathrm{C} 1 d-\mathrm{C} 1^{\prime}-\mathrm{C} 9 d-\mathrm{O} 4 d$ & $-176.76(18)$ \\
\hline \multirow[t]{2}{*}{$\mathrm{C} 9-\mathrm{C} 1-\mathrm{C} 1 \mathrm{~A}-\mathrm{O} 1 a$} & $166.69(15)$ & $\mathrm{C} 9 a-\mathrm{C} 1-\mathrm{C} 1 a-\mathrm{O} 1 a$ & $175.12(17)$ \\
\hline & & $\mathrm{C} 9 b-\mathrm{C} 1-\mathrm{C} 1 b-\mathrm{O} 1 b$ & $179.19(17)$ \\
\hline \multirow[t]{2}{*}{$\mathrm{C} 2 a-\mathrm{O} 1 a-\mathrm{C} 1 a-\mathrm{C} 1$} & $178.92(16)$ & $\mathrm{C} 9 c-\mathrm{C} 1^{\prime}-\mathrm{C} 1 c-\mathrm{O} 1 c$ & $-170.63(17)$ \\
\hline & & $\mathrm{C} 9 d-\mathrm{C}^{\prime}-\mathrm{C} 1 d-\mathrm{O} 1 d$ & $-178.26(18)$ \\
\hline
\end{tabular}


Table 3 continued

\begin{tabular}{lllr}
\hline Torsion angle & Torsion angle & \\
\hline $\mathrm{C} 1 a-\mathrm{O} 1 a-\mathrm{C} 2 a-\mathrm{C} 3 a$ & $177.74(18)$ & $\mathrm{C} 4 a-\mathrm{C} 3 a-\mathrm{C} 2 a-\mathrm{O} 1 a$ & $169.49(19)$ \\
$\mathrm{C} 4 a-\mathrm{C} 3 a-\mathrm{C} 2 a-\mathrm{O} 1 a$ & & $\mathrm{C} 4 b-\mathrm{C} 3 b-\mathrm{C} 2 b-\mathrm{O} 1 b$ & $177.04(19)$ \\
& $175.95(18)$ & $\mathrm{C} 4 c-\mathrm{C} 3 c-\mathrm{C} 2 c-\mathrm{O} 1 c$ & $-161.06(19)$ \\
& & $\mathrm{C} 4 d-\mathrm{C} 3 d-\mathrm{C} 2 d-\mathrm{O} 1 d$ & $178.6(2)$ \\
\hline
\end{tabular}

Symmetry code(s): (i) $-y+1, x-y-1, z$; (ii) $-x+y+2,-x+1, z$ Symmetry code: (i) $-y+1, x-y-1, z$; (ii) $-x+y+2,-x+1, z$ Symmetry code: (i) $-y+1, x-y-1, z$; (ii) $-x+y+2,-x+1, z$

Compound 2 crystallizes in hexagonal centrosymmetric $R^{-} 3$ space group with threefold axis lying along the direction of $\mathrm{C} 1-\mathrm{C} 9$ bond which means that the atoms $\mathrm{C} 1$ and C9 lie in the special position. The asymmetric unit contains the fragment which has one-third of $\mathrm{O} 4-\mathrm{H} 4$ hydroxyl group and one-third of $\mathrm{C} 1$ and $\mathrm{C} 9$ (including the hydrogen atoms attached to C9) atoms so the other twothirds are symmetry related. The location of $\mathrm{O} 4$ and $\mathrm{H} 4$ atoms in the unit cell is partial occupied with site occupancy factor equal to 0.33 (Fig. 2 shows only one O4-H4 hydroxyl group and one pair of hydrogen atoms attached to C9 for clarity). The molecular backbone of asymmetric unit fragment is almost completely planar, except for a rotation on the $\mathrm{C} 1-\mathrm{C} 9$ bond axis that bends the hydroxyl group (see torsions on the $\mathrm{C} 1-\mathrm{C} 9$ bond in Table 3).

Compound $\mathbf{3}$ crystallizes in monoclinic centrosymmetric $P 2_{1} / c$ space group with two molecules in the asymmetric unit. Intramolecular geometry analysis showed that bond lengths, angles, and torsion angles in molecule of compound 2 are in agreement with the same region of compound $\mathbf{3}$ (Table 3 ).

\section{Hydrogen bonding analyses}

The information on intramolecular hydrogen bonding, in particular, is very useful to understand various molecular properties (the molecular geometries, the stability of a certain predominant conformation, and, consequently, biological activity). As can be seen from Figs. 2 and 3, both compounds ( 2 and $\mathbf{3}$ ) contain intramolecular $\mathrm{O}-\mathrm{H}$...O hydrogen bonds connecting phenolic hydroxyl group and salicyloyl carbonyl group. In molecular structure of compound $\mathbf{3}$ two molecules in asymmetric unit are connected by bifurcated, and therefore weaker, hydrogen bonds, involving phenolic hydroxyl group and salicyloyl carbonyl group. Bifurcation of donors and acceptors forms a circle of hydrogen bonds. Crystal packings of two compounds ( 2 and 3 ) are illustrated in Fig. 4. As can be seen from Fig. 4a, crystal packing of compound $\mathbf{3}$ is dominantly arranged by the dense network of hydrogen bond mostly involving
$\mathrm{O} 4_{(a, b, c, d)}$ atom as donor or acceptor. The hydrogen bond parameters are given in Table 4.

Since we wanted to investigate the antioxidant behavior and cytotoxicity of compounds $\mathbf{2}$ and $\mathbf{3}$, we were interested in the conformation of molecules released from the influence of crystalline field. The next step, after determining the three-dimensional structures of these compounds in crystalline state, was to define the conformation of the molecules $\mathbf{2}$ and $\mathbf{3}$ in terms of energy minima. To do that both molecular geometries were optimized (MMFF94 force field: 500 steps of conjugate gradients followed by 500 steps of steepest descent with a convergence setting of 10e-7) using the program AVOGADRO 1.0.3 [34].

The conformation of molecules remains stable in their energy minima in spite of the significant number of interatomic single bonds. This is confirmed by comparing selected torsion angles of molecules, obtained in crystal structure analyses and after energy optimization (Table 5).

Figure 5 illustrates very good overlapping of the molecular structures in crystalline state and after optimization for both compounds ( 2 and $\mathbf{3}$ ). It seems that the presence of intramolecular hydrogen bonds in molecules stabilizes their conformations in spite of the possible influence of crystal packing. As illustrated in Fig. 5, the intramolecular $\mathrm{O}-\mathrm{H} . . . \mathrm{O}$ hydrogen bonds in both compounds ( $\mathbf{2}$ and $\mathbf{3}$ ) are preserved after energy minimization. This is the conformation in which intramolecular hydrogen bonds in compounds stabilize molecular conformation.

\section{Biological properties}

\section{Antioxidant activity of the synthesized salicylic acid derivatives}

The in vitro antioxidant activity of the synthesized salicyloyloxy derivatives was evaluated and compared with those of commercial antioxidants BHT and BHA (Table 6.). In the DPPH assay, the ability of tested compounds to act as donors of hydrogen atoms or electrons in transforming DPPH into its reduced form, DPPH-H, was measured by spectrophotometric method [14]. All tested 
a
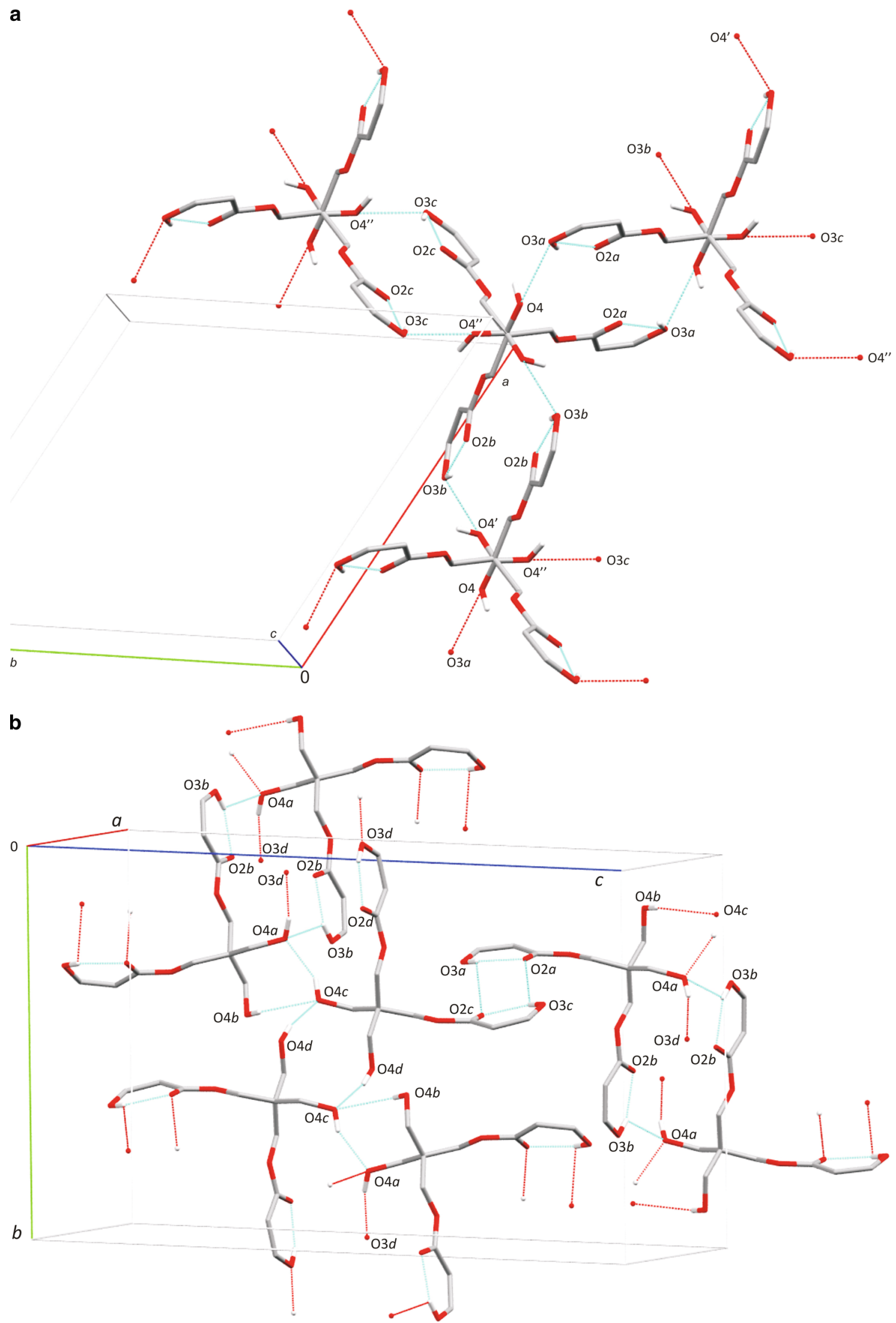

Fig. 4 Mercury [33] drawing showing the crystal packing of compound 2 (a) and $\mathbf{3}$ (b); hydrogen bonds are shown as dashed line 
Table 4 Intramolecular $\mathrm{O}-\mathrm{H}$...O hydrogen bond parameters $\left(\AA{ }^{\circ}{ }^{\circ}\right)$

\begin{tabular}{llllc}
\hline $\mathrm{D}-\mathrm{H} \ldots \mathrm{A}$ & $\mathrm{D}-\mathrm{H}$ & $\mathrm{H} \ldots \mathrm{A}$ & $\mathrm{D} \ldots \mathrm{A}$ & $\mathrm{D}-\mathrm{H} \ldots \mathrm{A}$ \\
\hline Compound 2 & & & & \\
$\mathrm{O} 3 a-\mathrm{H} 3 a \ldots \mathrm{O} 2 a$ & 0.82 & 1.93 & $2.645(3)$ & 146 \\
$\mathrm{O} 4-\mathrm{H} 4 \ldots \mathrm{O} 3 a^{1}$ & 0.82 & 2.36 & $2.569(7)$ & 97 \\
$\mathrm{O} 4{ }^{\prime}-\mathrm{H} 4 \ldots \mathrm{O} 3 b^{1}$ & & & & \\
$\mathrm{O} 4{ }^{\prime \prime}-\mathrm{H} 4 \ldots \mathrm{O} 3 c^{1}$ & & & & \\
$\mathrm{Compound} \mathrm{3}$ & & & & \\
$\mathrm{O} 3 a-\mathrm{H} 3 a \ldots \mathrm{O} 2 a$ & 0.82 & 1.94 & $2.632(2)$ & 142 \\
$\mathrm{O} 3 a-\mathrm{H} 3 a \ldots \mathrm{O} 2 c$ & 0.82 & 2.58 & $3.047(3)$ & 118 \\
$\mathrm{O} 3 b-\mathrm{H} 3 b \ldots \mathrm{O} 2 b$ & 0.82 & 1.94 & $2.657(2)$ & 145 \\
$\mathrm{O} 3 b-\mathrm{H} 3 b \ldots \mathrm{O} 4 a^{2}$ & 0.82 & 2.44 & $2.887(2)$ & 115 \\
$\mathrm{O} 3 c-\mathrm{H} 3 c \ldots \mathrm{O} 2 a$ & 0.82 & 2.41 & $2.948(3)$ & 124 \\
$\mathrm{O} 3 c-\mathrm{H} 3 c \ldots \mathrm{O} 2 c$ & 0.82 & 1.98 & $2.688(2)$ & 144 \\
$\mathrm{O} 3 d-\mathrm{H} 3 d \ldots \mathrm{O} 2 d$ & 0.82 & 1.88 & $2.597(2)$ & 146 \\
$\mathrm{O} 4 a-\mathrm{H} 4 a \ldots \mathrm{O} 3 d^{3}$ & 0.82 & 1.96 & $2.764(2)$ & 167 \\
$\mathrm{O} 4 b-\mathrm{H} 4 b \ldots \mathrm{O} 4 c^{4}$ & 0.82 & 2.24 & $3.255(3)$ & 146 \\
$\mathrm{O} 4 c-\mathrm{H} 4 c \ldots \mathrm{O} 4 a^{5}$ & 0.82 & 2.00 & $2.753(2)$ & 152 \\
$\mathrm{O} 4 d-\mathrm{H} 4 d \ldots \mathrm{O} 4 c^{6}$ & 0.82 & 1.98 & $2.787(2)$ & 166 \\
\hline
\end{tabular}

Symmetry codes: (1) $\mathrm{x}-\mathrm{y}+1 / 3,+\mathrm{x}-1 / 3-1,-\mathrm{z}+2 / 3$; (2) $1-$ $\mathrm{x},-\mathrm{y}, 1-\mathrm{z}$; (3) $1-\mathrm{x},-1 / 2+\mathrm{y}, 1 / 2-\mathrm{z}$; (4) $1+\mathrm{x}, 1 / 2-\mathrm{y}$, $1 / 2+\mathrm{z} ;(5)-1+\mathrm{x}, 1 / 2-\mathrm{y},-1 / 2+\mathrm{z} ;(6)-\mathrm{x},-\mathrm{y},-\mathrm{z}$

Table 5 Selected torsion angles $\left(^{\circ}\right)$

\begin{tabular}{lcc}
\hline & Crystal structure & Energy minimization \\
\hline Compound 2 & & \\
$\mathrm{C} 9-\mathrm{C} 1-\mathrm{C} 1 \mathrm{~A}-\mathrm{O} 1 a$ & $-65.2(4)$ & -63.5 \\
$\mathrm{C} 2 a-\mathrm{O} 1 a-\mathrm{C} 1 a-\mathrm{C} 1$ & $178.92(16)$ & 172.8 \\
$\mathrm{C} 1 a-\mathrm{O} 1 a-\mathrm{C} 2 a-\mathrm{C} 3 a$ & $177.74(18)$ & 178.4 \\
$\mathrm{C} 1-\mathrm{O} 1 a-\mathrm{C} 2 a-\mathrm{O} 2 a$ & $-2.9(3)$ & -2.4 \\
$\mathrm{Compound} 3$ & & \\
$\mathrm{C} 1 a-\mathrm{C} 1-\mathrm{C} 9 a-\mathrm{O} 4 a$ & $178.52(16)$ & -173.9 \\
$\mathrm{C} 1 b-\mathrm{C} 1-\mathrm{C} 9 a-\mathrm{O} 4 a$ & $57.5(2)$ & 66.1 \\
$\mathrm{C} 9 b-\mathrm{C} 1-\mathrm{C} 9 a-\mathrm{O} 4 a$ & $-61.0(2)$ & -52.9 \\
$\mathrm{C} 1 d-\mathrm{C} 1^{\prime}-\mathrm{C} 9 d-\mathrm{O} 4 d$ & $-176.76(18)$ & -177.7 \\
$\mathrm{C} 1 c-\mathrm{C} 1^{\prime}-\mathrm{C} 9 \mathrm{~d}-\mathrm{O} 4 d$ & $-55.3(2)$ & -57 \\
$\mathrm{C} 9 c-\mathrm{C} 1^{\prime}-\mathrm{C} 9 \mathrm{~d}-\mathrm{O} 4 d$ & $62.7(2)$ & 61.8 \\
$\mathrm{C} 1 a-\mathrm{O} 1 a-\mathrm{C} 2 a-\mathrm{O} 2 a$ & $-6.0(3)$ & -2.4 \\
$\mathrm{C} 1 a-\mathrm{O} 1 a-\mathrm{C} 2 a-\mathrm{C} 3 a$ & $174.27(17)$ & 179.3 \\
$\mathrm{C} 1 b-\mathrm{O} 1 b-\mathrm{C} 2 b-\mathrm{O} 2 b$ & $-0.6(3)$ & 1.1 \\
$\mathrm{C} 1 b-\mathrm{O} 1 b-\mathrm{C} 2 b-\mathrm{C} 3 b$ & $179.50(17)$ & -179.5 \\
$\mathrm{C} 1 c-\mathrm{O} 1 c-\mathrm{C} 2 c-\mathrm{O} 2 c$ & $2.9(3)$ & 2.1 \\
$\mathrm{C} 1 c-\mathrm{O} 1 c-\mathrm{C} 2 c-\mathrm{C} 3 c$ & $-178.48(17)$ & -179.3 \\
$\mathrm{C} 1 d-\mathrm{O} 1 d-\mathrm{C} 2 d-\mathrm{O} 2 d$ & $-2.1(3)$ & -0.9 \\
$\mathrm{C} 1 d-\mathrm{O} 1 d-\mathrm{C} 2 d-\mathrm{C} 3 d$ & $178.17(19)$ & 179.4 \\
\hline
\end{tabular}

compounds were able to reduce the stable purple-colored radical DPPH into yellow-colored DPPH-H form, though less than reference compounds (BHA and BHT). Among three tested substances, compound $\mathbf{1}$, containing four salicyloyl groups $\left(\mathrm{IC}_{50} 0.35 \mathrm{mM}\right)$, was the most potent, then compound 2, containing three salicyloyl groups, and the less potent was compound $\mathbf{3}$ possessing only two active groups.

The hydroxyl-radical scavenging activity of the examined compounds was measured by the deoxyribose assay [14]. The protective effects of the tested compounds on 2-deoxy-D-ribose were assessed as their ability to remove hydroxyl radicals (formed in the Fenton reaction) from the test solution and prevent the sugar degradation. The $\mathrm{OH}$ radical scavenging activity of the tested compounds was determined indirectly, by measuring the absorbance of the pink-colored solutions. All three compounds tested (1-3) expressed better scavenger properties than reference compounds, while compound $\mathbf{1}$, possessing four salicyloyl groups, was the most effective $\left(\mathrm{IC}_{50}\right.$ $0.40 \mathrm{mM})$.

\section{Cytotoxicity of the synthesized salicylic acid derivatives}

The cytotoxic effect of the synthesized compounds against ER+human breast adenocarcinoma (MCF-7), ER-human breast adenocarcinoma (MDA-MB-231), human prostate cancer (PC-3), and normal fetal lung fibroblasts (MRC-5) was examined by the standard SRB assay, after treatment of cells with the tested compounds during $48 \mathrm{~h}$ [29]. The results are presented in Table 6 .

As can be seen in Table 6, bis salicyloyl derivative $\mathbf{3}$ expressed cytotoxicity against all three tumor cell lines, while it was not toxic against healthy cells. Compound $\mathbf{3}$ showed the strongest cytotoxicity against prostate cancer PC-3 cells, even 13 times stronger than doxorubicin, while its effect was strong, but a little bit weaker against both breast cancer cell lines, MCF-7 and MDA-MB-231. Compounds $\mathbf{1}$ and $\mathbf{2}$ did not influence significantly on the tumor cells proliferation.

It is very important to emphasize that none of the newly synthesized compounds exhibited cytotoxicity against healthy MRC-5 cells. On the contrary, doxorubicin was highly toxic in very small doses.

\section{Effects of the synthesized salicylic acid derivatives on rat} $17 \beta H S D 2$

Inhibitory effects exerted on the $17 \beta \mathrm{HSD} 2$ activity by the newly synthesized compounds (1-3), investigated via measurement of testosterone to androst-4-ene-3,17-dione conversion by an adapted in vitro radiosubstrate incubation method [30-32], emphasized tris salicyloyl derivative $\mathbf{2}$ as the most potent $17 \beta \mathrm{HSD} 2$ inhibitor among the tested compounds (Table 6). Namely, $\mathrm{IC}_{50}$ value for this 


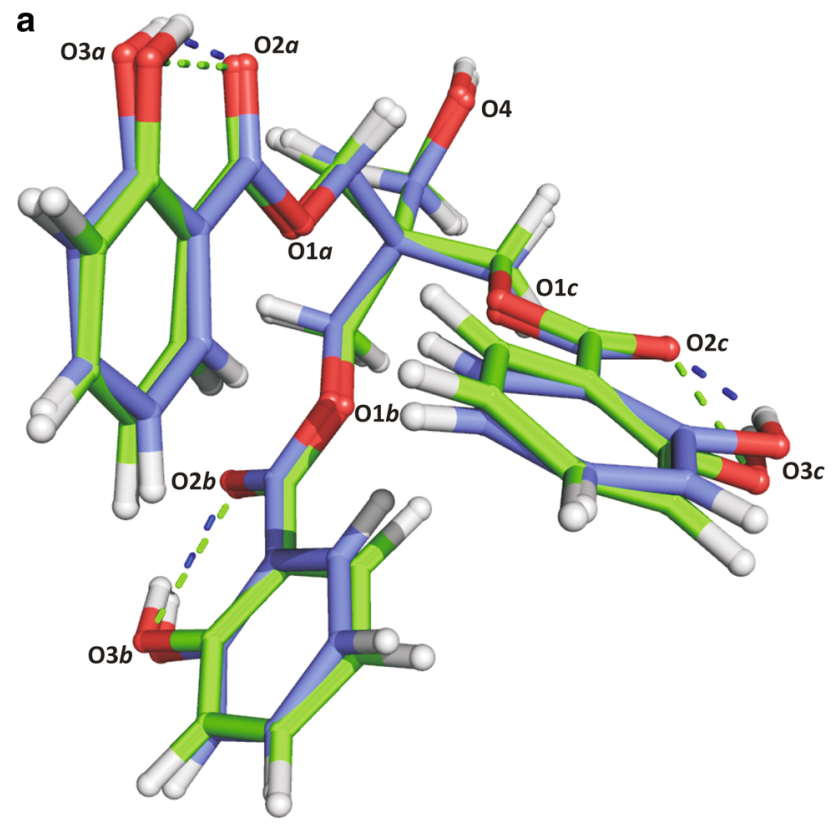

b

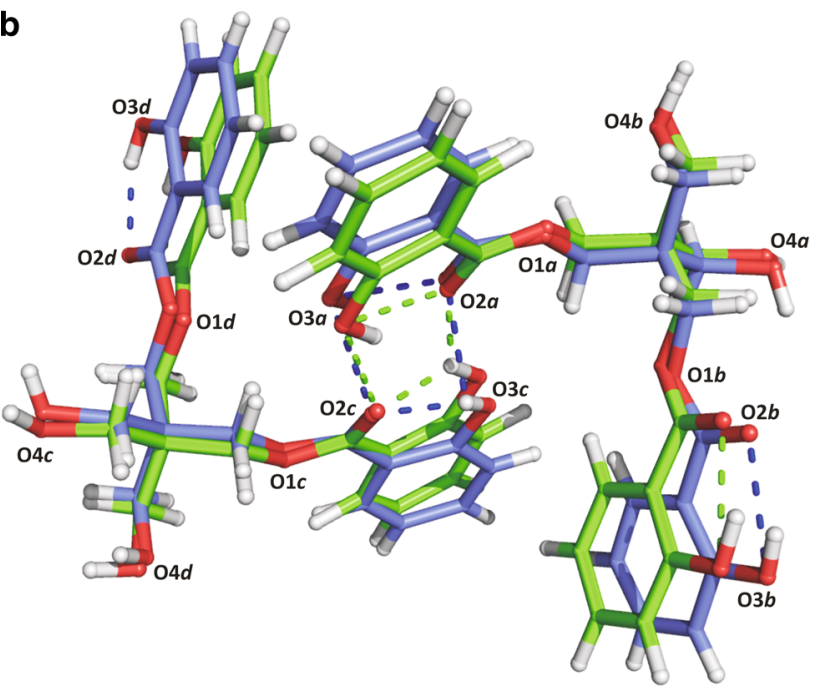

Fig. 5 Superimposed fit of the molecules after energy minimization ( $\mathrm{C}$ atoms in green) and the molecule in the crystalline state ( $\mathrm{C}$ atoms in blue): a compound $\mathbf{2}$ and $\mathbf{b}$ compound $\mathbf{3}$ (Color figure online) compound was $1.3 \mu \mathrm{M}$, which was 23 times stronger effect than bis salicyloyl derivative $\mathbf{3}$ and much stronger than tetrakis salicyloyl derivative $\mathbf{1}$.

\section{Conclusion}

The screening of biological properties of the newly synthesized compounds 1-3 showed that they are pharmacologically promising substances, each in different areas of antitumor drug search. Compound 1, containing four salicyloyl groups, was the most potent radical scavenger. Intramolecular geometry analysis of compound $\mathbf{2}$ and $\mathbf{3}$ (tris and bis salicyloyl derivatives) did not reveal major differences in their conformations, so it seems that the higher number of salicyloyl groups is the main reason for better antioxidant activity. Tris salicyloyl derivative $\mathbf{2}$ was potent $17 \beta \mathrm{HSD} 2$ inhibitor. Bis salicyloyloxy derivative 3 showed strong cytotoxicity against prostate and breast cancer cells, while it was not toxic against healthy cells.

Comparison of crystal and energy optimized structures for newly synthesized compounds $\mathbf{2}$ and $\mathbf{3}$ revealed that the intramolecular hydrogen bonds play an important role, stabilizing conformation of the most part of molecule. The influence of crystal packing on molecular conformation, including the dense network of intermolecular hydrogen bond especially in compound $\mathbf{3}$, is not predominant.

\section{Supplementary data}

Supplementary data CCDC 994056 and 994057 contain the supplementary crystallographic data for this paper. These data can be obtained free of charge at www.ccdc.cam.ac. uk/conts/retrieving.html [or from the Cambridge Crystallographic Data Centre (CCDC), 12 Union Road, Cambridge CB21EZ, UK; fax: +44(0)1223-336033; email: deposit@ccdc.cam.ac.uk].

Table 6 Radical scavenger activities, in vitro cytotoxicity and in vitro inhibition of rat 17 $\beta$-hydroxysteroid dehydrogenase type 2 (17 $\beta$ HSD2) of salicyloyl derivatives (1-3) and reference compounds; At least two experiments were performed with each test compound for each activity screening test, and the standard deviations of the mean results were within $\pm 10 \%$

\begin{tabular}{|c|c|c|c|c|c|c|c|c|}
\hline \multirow[t]{2}{*}{ Comp. } & \multicolumn{2}{|c|}{ Radical scavenger activity $\mathrm{IC}_{50}(\mathrm{mM})$} & \multicolumn{4}{|c|}{ Cytotoxicity $\mathrm{IC}_{50}(\mu \mathrm{M})$} & \multicolumn{2}{|c|}{ 17ßHSD2 inhibition } \\
\hline & DPPH & $\mathrm{OH}^{-}$ & MCF-7 & MDA-MB-231 & PC-3 & MRC-5 & Rel. conv. ${ }^{\mathrm{a}}(\%)$ & $\mathrm{IC}_{50}(\mu \mathrm{M})$ \\
\hline 1 & 0.35 & 0.40 & $>100$ & $>100$ & $>100$ & $>100$ & 64 & - \\
\hline 2 & 0.90 & 1.00 & $>100$ & $>100$ & $>100$ & $>100$ & - & 1.3 \\
\hline 3 & 3.70 & 1.00 & 10.64 & 18.64 & 7.21 & $>100$ & 39 & 30 \\
\hline BHT & 0.04 & 1.94 & - & - & - & - & - & - \\
\hline BHA & 0.01 & 2.13 & - & - & - & - & - & - \\
\hline DOX & - & - & 0.75 & 0.12 & 95.61 & 0.12 & - & - \\
\hline
\end{tabular}

${ }^{a}$ Conversion measured in the presence of $50 \mu \mathrm{M}$ of test compound, compared to conversion of control incubation with no inhibition (taken as $100 \%$ ) 
Acknowledgments Authors would like to thank the Hungary-Serbia IPA Cross-border Co-operation Programme (Project No. HUSRB/ 1002/214/133 RECODAC) and to the Provincial Secretariat for Science and Technological Development of the Autonomous Province of Vojvodina (Grant No. 114-451-3600/2013-02).

\section{References}

1. Dröge W (2002) Free radicals in the physiological control of cell function. Physiol Rev 82:47-95

2. Valko M, Leibfritz D, Moncol J, Cronin MTD, Mazur M, Telser J (2007) Free radicals and antioxidants in normal physiological functions and human disease. Int J Biochem Cell Biol 39:44-84

3. Hollman PCH (2001) Evidence for health benefits of plant phenols: local or systemic effects? J Sci Food Agric 81:842-852

4. Hatanaka M, Takahashi K, Nakamura S, Mashino T (2005) Preparation and antioxidant activity of $\alpha$-pyridoin and its derivatives. Bioorg Med Chem 13:6763-6770

5. Ljubuncic P, Azaizeh H, Portnaya I, Cogan U, Said O, Abu Saleh K, Bomzon A (2005) Antioxidant activity and cytotoxicity of eight plants used in traditional Arab medicine in Israel. J Ethnopharmacol 99:43-47

6. Al-Dabbas MM, Suganuma T, Kitahara K, Hou D, Fujii M (2006) Cytotoxic, antioxidant and antibacterial activities of Varthemia iphionoides Boiss. extracts. J Ethnopharmacol 108:287-293

7. Gomes CA, Girão da Cruz T, Andrade JL, Milhazes N, Borges F, Marques MPM (2003) Anticancer activity of phenolic acids of natural or synthetic origin: a structure-activity study. J Med Chem 46:5395-5401

8. Simpson J, Forrester R, Tisdale MJ, Billington DC, Rathbone DL (2003) Effect of catechol derivatives on cell growth and lipoxygenase activity. Bioorg Med Chem Lett 13:2435-2439

9. Ekinci D, Sentürk M, Küfrevioglu ÖI (2011) Salicylic acid derivatives: synthesis, features and usage as therapeutic tools. Expert Opin Ther Pat 21(12):1831-1841

10. Kubo I, Masuoka N, Joung Ha T, Tsujimoto K (2006) Antioxidant activity of anacardic acids. Food Chem 99:555-562

11. Fletcher S, Singh J, Zhang X, Yue P, Page BDG, Sharmeen S, Shahani VM, Zhao W, Schimmer AD, Turkson J, Gunning PT (2009) Disruption of transcriptionally active Stat3 dimers with nonphosphorylated, salicylic acid-based small molecules: potent in vitro and tumor cell activities. ChemBioChem 10(12):1959-1964

12. Logrado LPL, Silveira D, Romeiro LAS, De Moraes MO, Cavalcanti BC, Costa-Lotufo LV, Do Ó, Pessoa C, Dos Santos ML (2005) Synthesis and biological evaluation of new salicylate macrolactones from anacardic acids. J Braz Chem Soc 16:1217-1225

13. Ott I, Kircher B, Schumacher P, Schmidt K, Gust R (2005) Antitumor active cobalt-alkyne complexes derived from acetylsalicylic acid: studies on the mode of drug action. J Med Chem 48:622-629

14. Djurendić EA, Dojčinović-Vujašković SV, Sakač MN, Jovin ED, Kojić VV, Bogdanović GM, Klisurić OR, Stanković SM, Lazar DV, Fabian L, Penov-Gaši KM (2010) X-ray structural analysis, antioxidant and cytotoxic activity of newly synthesized salicylic acid derivatives. Struct Chem 21:67-78

15. Djurendić EA, Dojčinović-Vujašković SV, Sakač MN, Ajduković JJ, Gaković AR, Kojić VV, Bogdanović GM, Klisurić OR, Penov-Gaši KM (2011) Synthesis and biological evaluation of some new 2-oxazoline and salicylic acid derivatives. Arkivoc ii:83-102

16. Fujimori T, Yamada S, Yasui H, Sakurai H, Ishida YIT (2005) Orally active antioxidative copper(II) aspirinate: synthesis, structure characterization, superoxide scavenging activity, and in vitro and in vivo antioxidative evaluations. J Biol Inorg Chem 10:831-841
17. Su EJ, Cheng YH, Chatterton RT, Lin ZH, Yin P, Reierstad S, Innes J, Bulun SE (2007) Regulation of 17-beta hydroxysteroid dehydrogenase type 2 in human placental endothelial cells. Biol Reprod 77:517-525

18. Vihko P, Herrala A, Härkönen P, Isomaa V, Kaija H, Kurkela R, Li Y, Patrikainen L, Pulkka A, Soronen P, Törn S (2005) Enzymes as modulators in malignant transformation. J Steroid Biochem 93:277-283

19. Marchais-Oberwinkler S, Xu K, Wetzel M, Perspicace E, Negri M, Meyer A, Odermatt A, Möller G, Adamski J, Hartmann RW (2013) Structural optimization of 2,5-thiophene amides as highly potent and selective 17 $\beta$-hydroxysteroid dehydrogenase type 2 inhibitors for the treatment of osteoporosis. J Med Chem 56: 167-181

20. Penov Gaši K, Djurendić E, Dojčinović-Vujašković S, Gaković A, Jovanović-Šanta S, Kojić V, Sakač M (2012) Synthesis, anti-oxidant activity, and cytotoxicity of salicyloyl derivatives of estra1,3,5(10)-triene and androst-5-ene. Chem Pap 66(4):284-294

21. Djurendić EA, Vastag GyGy, Surányi TM, Popsavin MM, PenovGaši KM (2000) Synthesis of some bis- and mono-2-hydroxybenzoic acid derivatives and the determination of their acidity constants. J Serb Chem Soc 65:681-689

22. Minagawa M, Sekiguchi T, Tsuruga K (1979) Aromatic carboxylic acid ester stabilizers for PVC resins. Patent number US 4134868

23. Oxford Diffraction CrysAlis CCD and CrysAlis RED. Versions 1.171 (2008) Oxford Diffraction Ltd, Abingdon, Oxfordshire, England

24. Altomare A, Cascarano G, Giacovazzo C, Guagliardi A (1993) Completion and refinement of crystal structures with SIR92. J Appl Cryst 26:343-350

25. Sheldrick GM (1997) SHELX97, programs for crystal structure analysis. University of Göttingrn, Germany

26. Nardelli MJ (1995) PARST95 — an update to PARST: a system of Fortran routines for calculating molecular structure parameters from the results of crystal structure analyses. J Appl Cryst 28:659-662

27. Spek AL (1998) PLATON, a multipurpose crystallographic tool. University of Utrecht, The Netherlands

28. Farrugia LJ (1999) WinGX suite for small-molecule singlecrystal crystallography. J Appl Cryst 32:837-838

29. Skehan P, Storeng R, Scudiero D, Monks A, McMahon J, Vistica D, Warren TJ, Bokesch H, Kenney S, Boyd RM (1990) New colorimetric cytotoxicity assay for anticancer-drug screening. J Natl Cancer 82:1107-1112

30. Tóth I, Szécsi M, Julesz J, Faredin I (1997) Activity and inhibition of 3-beta-hydroxysteroid dehydrogenase/delta-5-4-isomerase in human skin. Skin Pharmacol 10(3):160-168

31. Darvas B, Székács A, Fónagy A, Szécsi M, Tóth I (1997) Progesterone in Periplaneta americana and Neobellieria bullata adults from the procuticle phase until first progeny production. Gen Comp Endocrinol 107(3):450-460

32. Akinola LA, Poutanen M, Vihko R, Vihko P (1997) Expression of $17 \beta$-hydroxysteroid dehydrogenase type 1 , and type 2 , p450 aromatase, and 20 $\alpha$-hydroxysteroid dehydrogenase enzymes in immature, mature, and pregnant rats. Endocrinology 138:2886-2892

33. Bruno IJ, Cole JC, Edgington PR, Kessler MK, Macrae CF, McCabe P, Pearson J, Taylor R (2002) New software for searching the Cambridge Structural Database and visualizing crystal structures. Acta Cryst B58:389-397

34. Hanwell MD, Curtis DE, Lonie DC, Vandermeersch T, Zurek E, Hutchison GR (2012) Avogadro: an advanced semantic chemical editor, visualization, and analysis platform. J Cheminform 4:17 